\title{
Aktivitas Antioksidan Isolat Steroid Hasil Kromatografi Lapis Tipis dari Fraksi n-Heksana Hydrilla verticillata
}

\author{
Ahmad Ghanaim Fasya ${ }^{1 *}$, Bagas Purwantoro', Lulu'atul Hamidatu Ulya', Mujahidin Ahmad² \\ 1 Jurusan Kimia, Fakultas Sains dan Teknologi, Universitas Islam Negeri Maulana Malik Ibrahim, Malang, Indonesia, 65144 \\ 2Jurusan Biologi, Fakultas Sains dan Teknologi, Universitas Islam Negeri Maulana Malik Ibrahim, Malang, Indonesia, 65144
}

\section{INFO ARTIKEL}

\section{Riwayat Artikel}

Diterima 3 Juni 2020

Direvisi 23 Juni 2020

Tersedia online 14 Juli 2020

\footnotetext{
*Email penulis korespondensi: fasya.organik@kim.uin-malang.ac.id
}

\section{ABSTRAK}

Hydrilla verticillata is one of Allah SWT creations that potential as an antioxidant. This study's objectives were to determine antioxidant activity and identify steroid isolates of $n$-hexane fraction of $H$. verticillata. The steroid compounds were extracted using methanol solvent. The methanol extract was hydrolyzed with $\mathrm{HCl}$ $2 \mathrm{~N}$ and partitioned using $\mathrm{n}$-hexane. The $\mathrm{n}$-hexane fraction was tested phytochemically and separated using thin-layer chromatography (TLC). The steroids compounds were identified using UV-Vis spectrophotometer, FTIR, and LC-MS/MS. The result showed that maceration extraction produced $5.14 \%$ yield, whereas $n$-hexane fraction produce $47.95 \%$ yield. Steroid separation through analytical TLC revealed that $n$-hexane: ethyl acetate $(4: 1)$ as the best eluant with 12 spots, while separation using preparative TLC yielded 19 spots. Steroid isolate from TLC preparative has antioxidant activity with $\mathrm{EC}_{50}$ of $5.109 \mathrm{ppm}$. Identification of steroid compounds using UV-Vis produced maximum wavelengths at 203.9 and $276 \mathrm{~nm}$, while using FTIR indicated the presence of $\mathrm{O}-\mathrm{H}$ group, geminal dimethyl, $\mathrm{C}=\mathrm{O}, \mathrm{C}=\mathrm{C}$, secondary $\mathrm{C}-\mathrm{OH}$, and $=\mathrm{C}-\mathrm{H}$ (alkene) which might contain steroid compounds. The result of LC-MS/MS showed the presence of $\beta$-sitosterol.

Keywords: Hydrilla verticillata, steroid compounds, thin-layer chromatography, antioxidant assay, UV-Vis, FTIR, LC-MS/MS

Hydrilla verticillata merupakan salah satu ciptaan Allah SWT yang memiliki potensi sebagai antioksidan. Penelitian ini bertujuan mengetahui aktivitas antioksidan dan mengidentifikasi senyawa steroid pada isolat hasil pemisahan fraksi n-heksana $\mathrm{H}$. verticillata. Senyawa steroid diekstraksi menggunakan pelarut metanol. Ekstrak pekat metanol dihidrolisis dengan $\mathrm{HCl} 2 \mathrm{~N}$ dan dipartisi dengan n-heksana. Fraksi n-heksana hasil partisi diuji fitokimia dan dipisahkan senyawanya menggunakan KLT (Kromatografi Lapis Tipis). Identifikasi dilakukan menggunakan UV-Vis, FTIR, dan LC-MS/MS. Hasil penelitian menunjukkan ekstraksi maserasi menghasilkan rendemen $5,14 \%$, sedangkan rendemen partisi n-heksana sebesar $47,95 \%$. Pemisahan steroid menggunakan KLT analitik menunjukkan bahwa variasi eluen terbaik adalah n-heksana: etil asetat (4:1) dengan 12 noda, sedangkan pemisahan KLT preparatif menghasilkan 19 noda. Isolat steroid hasil KLT preparatif memiliki aktivitas antioksidan dengan $\mathrm{EC}_{50}$ 5,109 ppm. Identifikasi senyawa steroid menggunakan UV-Vis menunjukkan bahwa panjang gelombang maksimum sebesar 203,9 dan $276 \mathrm{~nm}$, sedangkan untuk identifikasi isolat steroid menggunakan FTIR menunjukkan gugus fungsi $\mathrm{O}-\mathrm{H}$, geminal dimetil, $\mathrm{C}=\mathrm{O}, \mathrm{C}=\mathrm{C}$, $\mathrm{C}-\mathrm{OH}$ sekunder dan $=\mathrm{C}-\mathrm{H}$ (alkena) yang diduga merupakan senyawa steroid. Hasil LC-MS/MS menunjukkan adanya senyawa steroid $\beta$-sitosterol.

Kata kunci: Hydrilla verticillata, steroid, kromatografi lapis tipis, uji antioksidan, UVVis, FTIR, LC-MS/MS 


\section{Pendahuluan}

Keanekaragaman sumberdaya alam di Indonesia baik hayati maupun nonhayati perlu dieksplorasi, salah satunya sebagai sumber senyawa aktif yang berpotensi untuk bahan obat. Hal ini didukung wilayah Indonesia yang berada di daerah tropis dan sebagian besar $(75 \%)$ terdiri dari perairan, baik air laut ataupun air tawar. Selain itu, jumlah danau yang ada di Indonesia sangat banyak yaitu 526 danau. Namun, hanya sedikit danau yang potensi alamnya telah dikaji dan dimanfaatkan secara mendalam [1]. Seperti halnya Danau Ranu yang terletak di Kabupaten Pasuruan, danau ini memiliki keanekaragaman hayati yang tinggi salah satunya adalah Hydrilla (Hydrilla verticillata (L.f) Royle) atau lebih dikenal oleh masyarakat setempat sebagai "ganggeng".

Tumbuhan hydrilla masih belum banyak dimanfaatkan karena kurangnya pengetahuan dari masyarakat. Di Indonesia, pemanfaatan hydrilla masih terbatas sebagai tanaman hias untuk akuarium. Hydrilla sering dianggap sebagai ancaman bagi ekosistem danau dan sungai karena pertumbuhannya yang cepat [1]. $H$. verticillata dapat dimanfaatkan dalam fitoremediasi pada pengolahan limbah [2] dan diproduksi sebagai suplemen. Tumbuhan ini juga dimanfaatkan di bidang kesehatan antara lain sebagai obat antitumor, antibakteri [3, 4], antimikroba [5], antimalaria [6], dan antioksidan [7, 8] serta sebagai adsorben terbaik untuk beberapa logam berat [9].

$H$. verticillata mengandung berbagai metabolit sekunder. Kensa dan Neelamegam [10] menyebutkan hasil skrining $H$. verticillata mengandung metabolit sekunder yaitu flavonoid, alkaloid, dan steroid. Penelitian lain menyebutkan hasil skrining H. verticillata mengandung fenol, glikosida, alkaloid, dan steroid [11]. Penelitian yang dilakukan oleh Amalia dkk. [12] dan Fasya dkk. [8] menyatakan bahwa fraksi petroleum eter hasil hidrolisis ekstrak etanol $\mathrm{H}$. verticillata mengandung steroid.

Kandungan senyawa aktif $H$. verticillata dapat diperoleh dengan ekstraksi maserasi. Metode maserasi sering dipilih karena aman digunakan dan dapat mengantisipasi senyawa yang tidak tahan panas. Proses ini sangat menguntungkan dalam proses isolasi bahan alam karena mampu memecah dinding dan membran sel akibat perbedaan tekanan di dalam dan di luar sel sehingga senyawa metabolit sekunder akan larut dalam pelarut organik. Mardiyah [13] menyatakan bahwa senyawa metabolit sekunder di alam berada dalam bentuk glikosida sehingga ekstraksi dilakukan menggunakan pelarut yang bersifat polar.

Menurut Lenny [14], pelarut yang sering digunakan dalam proses isolasi senyawa organik bahan alam adalah pelarut golongan alkohol, salah satunya metanol. Metanol dapat melarutkan senyawa metabolit sekunder dan memiliki titik didih yang rendah sehingga mudah diuapkan [15]. Hafiz [16] telah melakukan ekstraksi maserasi $H$. verticillata dengan menggunakan variasi pelarut antara lain metanol (polar), kloroform (semi polar), dan n-heksana (non polar). Rendemen yang didapat dengan pelarut metanol sebesar $12,72 \%$. Adapun ekstraksi dengan pelarut kloroform dan $n$-heksana didapat rendemen yang lebih kecil yaitu masing-masing sebesar 4,96 dan 3,80\%. Oleh karena itu, pada penelitian ini digunakan pelarut metanol untuk ekstraksi maserasi.

Pemisahan yang lebih spesifik dapat dilakukan dengan cara hidrolisis untuk memutuskan ikatan antara glikon dan steroid [17]. Senyawa sterol yang merupakan salah satu jenis steroid ditemukan pada tumbuhan dalam keadaan berikatan dengan glikosida [18]. Pemutusan ikatan glikosida menjadi steroid dan glikon dapat dilakukan dengan hidrolisis menggunakan larutan $\mathrm{HCl} 2 \mathrm{~N}$ [19]. Partisi dilakukan untuk mengambil metabolit sekunder yang diinginkan yang mempunyai kesamaan kepolaran dengan pelarut [20]. Tonius dkk. [21] menyatakan bahwa fraksi n-heksana daun buasbuas (Premna serratifolia L.) diduga mengandung cholestane yang termasuk dalam salah satu golongon steroid. Fraksi yang diperoleh dari hasil partisi biasanya masih berupa senyawa campuran sehingga perlu dilakukan isolasi lebih lanjut.

Isolasi senyawa steroid dapat dilakukan dengan metode kromatografi lapis tipis (KLT) [22, 23]. Mardaneni [24] menggunakan eluen $\mathrm{n}$-heksana : etil asetat $(17: 3)$ pada fraksi etil asetat alga merah menghasilkan 6 noda. Baderos [25] menyatakan bahwa identifikasi golongan steroid dari fraksi petroleum eter alga merah menggunakan eluen $\mathrm{n}$-heksana : etil asetat (17:3) menunjukkan 11 noda di bawah sinar UV $366 \mathrm{~nm}$. Noda yang menunjukkan adanya steroid adalah noda ke5, 6, 7, 9, 10 dan 11. Penelitian Azah [26] menyatakan bahwa identifikasi golongan steroid pada $H$. verticillata dengan fase gerak n-heksana: etil asetat $(3,75: 1,25)$ diperoleh 13 noda dan 2 noda merupakan senyawa steroid.

Pengujian aktivitas antioksidan dari senyawa steroid dilakukan dengan metode 1,1-difenil-2-pikrilhidrazil (DPPH). Hasil uji antioksidan pada tumbuhan $\mathrm{H}$. verticillata dengan menggunakan pelarut metanol, kloroform, dan $\mathrm{n}$-heksana diperoleh nilai $\mathrm{EC}_{50}$ masing-masing 256,6; 457,6 dan 2763 ppm [27]. Laili [28] melakukan uji antioksidan terhadap fraksi petroleum alga merah menunjukkan bahwa nilai $\mathrm{EC}_{50}$ yaitu 248,1 ppm. Fasya dkk. [29] melakukan uji aktivitas antioksidan isolat KLT preparatif fraksi petroleum eter mikroalga Chlorella sp. dan diperoleh nilai $\mathrm{EC}_{50}$ sebesar $73,83 \mathrm{ppm}$. Adapun nilai $\mathrm{EC}_{50}$ isolat steroid hasil kromatografi kolom dari fraksi petroleum eter hasil hidrolisis ekstrak etanol $\mathrm{H}$. verticillata sebesar $23,00 \mathrm{ppm}[8]$. 
Pada penelitian ini dilakukan pengujian aktivitas antioksidan isolat hasil KLT preparatif fraksi $n$-heksana dari $H$. verticillata dengan metode DPPH dan mengidentifikasi senyawa steroid dalam fraksi $n$-heksana dengan menggunakan instrumentasi UV-Vis (Ultraviolet-visible), FTIR (Fourier-Transform Infrared) dan LC-MS/MS (Liquid ChromatorgraphyMass Spectrometry). Hasil dari penelitian ini akan diaplikasikan sebagai sumber senyawa antioksidan alami.

\section{Bahan dan Metode}

\subsection{Bahan}

Bahan sampel yang digunakan dalam penelitian ini adalah $H$. verticillata yang berasal dari Danau Ranu Grati, Pasuruan. Bahan-bahan kimia yang digunakan adalah metanol 96\% (p.a), kloroform 96\% (p.a), n-heksana 96\% (p.a),

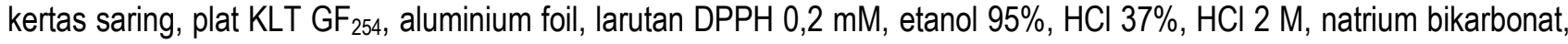
dan reagen Lieberman-Burchard (asam asetat anhidrat, $\mathrm{H}_{2} \mathrm{SO}_{4}$ pekat, dan etanol absolut).

\subsection{Preparasi Sampel}

Pengambilan sampel di Danau Ranu dilakukan di permukaan air dimana jarak antara permukaan dengan dasar air \pm $2 \mathrm{~m}$. Sampel diambil sebanyak $10 \mathrm{~kg}$ dan dicuci dengan air. Selanjutnya, dikeringkan di bawah sinar matahari secara tidak langsung sampai kering. Setelah itu, sampel kering dihaluskan dengan ukuran 90 mesh dan dikeringkan pada suhu $38^{\circ} \mathrm{C}$ selama 24 jam di Materia Medika, Kota Batu.

\subsection{Penentuan Kadar Air}

Cawan porselen disiapkan terlebih dahulu, lalu dipanaskan dalam oven pada suhu $100-105^{\circ} \mathrm{C}$ sekitar 15 menit untuk menghilangkan kadar air. Selanjutnya, cawan disimpan dalam desikator sekitar 10 menit, ditimbang dan dilakukan perlakuan yang sama sampai diperoleh berat cawan yang konstan. Setelah itu, sebanyak $5 \mathrm{~g}$ sampel dimasukkan dalam cawan porselen, kemudian dimasukkan dalam oven dan dikeringkan pada suhu $100-105^{\circ} \mathrm{C}$ sekitar \pm 15 menit. Sampel kemudian disimpan dalam desikator sekitar \pm 10 menit dan ditimbang. Sampel tersebut dipanaskan kembali dalam oven \pm 15 menit, didinginkan dalam desikator sekitar \pm 10 menit dan ditimbang kembali. Perlakuan ini diulangi hingga tercapai berat konstan. Kadar air dalam serbuk $H$. verticillata dihitung menggunakan Persamaan (1).

$$
\text { Kadar air }=\frac{(b-c)}{(b-a)} \times 100 \%
$$

Dimana, a adalah bobot cawan kosong, $b$ adalah bobot sampel ditambah cawan sebelum dikeringkan, dan $\mathrm{c}$ adalah bobot cawan ditambah sampel setelah dikeringkan.

\subsection{Ekstraksi Sampel}

Ekstraksi komponen aktif dilakukan dengan cara ekstraksi maserasi. Sampel $H$. verticillata yang telah dihaluskan kemudian ditimbang sebanyak $50 \mathrm{~g}$ dan diekstraksi secara maserasi menggunakan pelarut metanol $96 \%$ dengan perbandingan $5: 1(\mathrm{~b} / \mathrm{v})$ sebanyak 3 kali dan dilakukan pengocokan menggunakan shaker selama 3 jam dengan kecepatan $120 \mathrm{rpm}$. Setelah itu, dilakukan penyaringan menggunakan corong Buchner. Ekstrak pekat ditimbang lalu dihitung rendemennya dengan Persamaan 2.

$$
\text { Rendemen }(\%)=\frac{\text { berat ekstrak }}{\text { berat sampel }} \times 100 \%
$$

\subsection{Hidrolisis dan Partisi}

Hidrolisis ekstrak metanol $H$. verticillata dilakukan dengan cara penambahan $\mathrm{HCl} 2 \mathrm{M}$. Selanjutnya, ditambahkan natrium bikarbonat sampai pH 7 (netral). Ekstrak pekat metanol $H$. verticillata yang diperoleh pada proses sebelumnya dipindahkan ke dalam corong pisah dan dipartisi dengan pelarut n-heksana. Pelarut n-heksana ditambahkan sebanyak 25 $\mathrm{mL}$ kemudian dikocok dan didiamkan hingga terbentuk dua lapisan yaitu lapisan organik dan lapisan air. Masing-masing lapisan yang terbentuk kemudian dipisahkan, lapisan air yang ada di bagian bawah ditampung dan dimasukkan lagi ke corong pisah. Proses partisi dilakukan hingga diperoleh fasa air bening. Lapisan organik dimasukkan ke dalam gelas kimia kemudian dipekatkan dengan rotary evaporator vacuum lalu dialiri dengan gas $\mathrm{N}_{2}$. Ekstrak pekat yang diperoleh selanjutnya ditimbang dan dihitung rendemennya [30].

\subsection{Uji Fitokimia Senyawa Steroid}

Uji fitokimia dilakukan dengan melarutkan fraksi n-heksana dalam $0,5 \mathrm{~mL}$ kloroform, kemudian ditambahkan $0,5 \mathrm{~mL}$ asam asetat anhidrida dan 1-2 $\mathrm{mL}$ asam sulfat pekat (melalui dinding tabung). Apabila terbentuk warna hijau kebiruan menunjukkan adanya golongan senyawa steroid. 


\subsection{Pemisahan Senyawa Steroid dengan Kromatografi Lapis Tipis (KLT)}

\subsubsection{Pemisahan dengan KLT Analitik}

Pemisahan senyawa steroid dengan KLT analitik menggunakan metode modifikasi Sriwahyuni [31]. Identifikasi dengan $\mathrm{KLT}$ menggunakan plat silika gel $\mathrm{GF}_{254}$ yang diaktivasi terlebih dahulu dalam oven pada suhu $100^{\circ} \mathrm{C}$ selama 30 menit untuk menghilangkan air yang terdapat pada plat. Selanjutnya, masing-masing plat diberi ukuran $1 \times 10 \mathrm{~cm}$.

Ekstrak $H$. verticillata diperoleh dengan melarutkan ekstrak kasar sebanyak $10 \mathrm{mg}$ dengan $1 \mathrm{~mL}$ pelarut $\mathrm{n}$-heksana. Ekstrak $H$. verticillata kemudian ditotolkan pada jarak $\pm 1 \mathrm{~cm}$ dari tepi bawah plat dengan pipa kapiler dan dalam 1 plat $\mathrm{KLT}$ diberi 1 totolan dimana dalam 1 tempat totolan diberikan 3-5 kali penotolan. Plat yang sudah berisi totolan tersebut, kemudian dikeringkan dan dielusi dengan masing-masing fase gerak (eluen).

Eluen untuk pengembangan ini dilakukan penjenuhan terlebih dahulu dalam suatu bejana tertutup selama 20-30 menit. Penjenuhan ini dilakukan untuk menyamakan tekanan uap pada seluruh bagian bejana. Setelah gerakan fase gerak sampai pada garis batas, elusi dihentikan. Noda-noda pada permukaan plat diperiksa di bawah sinar UV pada panjang gelombang $366 \mathrm{~nm}$, diamati pemisahan noda dan dihitung nilai Rf-nya. Pada penelitian ini digunakan 5 macam variasi eluen (Tabel 1).

Tabel 1. Variasi Eluen Campuran n-Heksana dan Etil Asetat

\begin{tabular}{ccc}
\hline Eluen & Perbandingan $\mathbf{n}$-Heksana : Etil Asetat & Referensi \\
\hline 1 & $4,75: 0,25$ & {$[32]$} \\
2 & $4,50: 0,50$ & {$[33]$} \\
3 & $4,25: 0,75$ & {$[34]$} \\
4 & $4,00: 1,00$ & {$[35]$} \\
5 & $3,75: 1,25$ & {$[36]$} \\
\hline
\end{tabular}

\subsubsection{Pemisahan KLT Preparatif}

Pemisahan dengan KLT preparatif digunakan plat silika gel $\mathrm{GF}_{254}$ dengan ukuran $10 \times 20 \mathrm{~cm}$. Ekstrak pekat hasil ekstraksi ditotolkan sepanjang plat pada jarak $1 \mathrm{~cm}$ dari garis bawah dan $1 \mathrm{~cm}$ dari garis tepi. Selanjutnya, dielusi dengan menggunakan eluen yang memberikan pemisahan terbaik pada KLT analitik. Noda-noda pada permukaan plat diperiksa di bawah sinar UV pada panjang gelombang $366 \mathrm{~nm}$, kemudian diamati pada masing-masing hasil nodanya. Noda yang diduga merupakan senyawa steroid dikerok dan dilarutkan dalam $5 \mathrm{~mL}$ pelarut $n$-heksana, selanjutnya disentrifugasi untuk mengendapkan silika.

\subsection{Uji Aktivitas Antioksidan dengan Metode DPPH}

\subsubsection{Penentuan Panjang Gelombang Maksimum DPPH}

Etanol 95\% dipipet sebanyak 4,5 mL kemudian ditambahkan larutan DPPH 0,2 mM sebanyak 1,5 mL dan dimasukkan ke dalam kuvet. Selanjutnya, ditentukan dan dicatat hasil pengukuran $\lambda_{\max }$ DPPH untuk digunakan pada tahap selanjutnya [37].

\subsubsection{Pengukuran Aktivitas Antioksidan pada Sampel}

Masing-masing isolat dilarutkan dalam etanol $95 \%$ dengan konsentrasi 50 ppm dan diuji aktivitas antioksidannya. Ekstrak untuk uji aktivitas antioksidan divariasikan konsentrasi menjadi 1, 2, 3, 4, dan 5 ppm. Ekstrak pada masing-masing konsentrasi dipipet 4,5 mL dan ditambahkan 1,5 mL DPPH 0,2 mM kemudian diinkubasi dengan suhu $37^{\circ} \mathrm{C}$ selama 90 menit, dan diukur absorbansinya menggunakan spektrofotometer UV-Vis pada $\lambda_{\max }$ yang telah didapatkan. Data absorbansinya yang diperoleh digunakan untuk menghitung persen (\%) aktivitas antioksidan menggunakan Persamaan (3) dan ditentukan pula nilai $\mathrm{EC}_{50}$ nya [27].

$$
\text { Aktivitas antioksidan }(\%)=\frac{\text { (Absorbansi sampel }- \text { Absorbansi kontrol) }}{\text { Absorbansi kontrol }} \times 100 \%
$$

\subsection{Identifikasi Senyawa Steroid}

\subsubsection{Identifikasi dengan Spektrofotometer UV-Vis}

Isolat yang diperoleh dari hasil KLT preparatif yang diduga senyawa steroid dianalisis dengan menggunakan spektrofotometer UV-Vis. Isolat dimasukkan dalam kuvet dan dianalisis pada rentang panjang gelombang 200-800 nm. Blanko yang digunakan adalah pelarut $n$-heksana yang dianalisis rentang panjang gelombang yang sama dengan isolat. Spektra yang terbentuk diamati, dicatat panjang gelombang dan absorbansinya pada puncak yang terbentuk. 


\subsubsection{Identifikasi dengan FTIR}

Hasil isolat steroid $n$-heksana dan petroleum eter yang menunjukkan nilai aktivitas antioksidan terbaik diidentifikasi menggunakan FTIR. Ekstrak kasar tersebut dicampur dengan pelet $\mathrm{KBr}$ lalu digerus bersamaan dengan mortar agate. Campuran pelet $\mathrm{KBr}$ dan sampel yang telah halus ditekan dengan tekanan 80 torr ( 8 - 20 Torr per satuan waktu) selama 10 menit. Selanjutnya, pelet yang telah ditekan dianalisis menggunakan FTIR.

\subsubsection{Identifikasi dengan LC-MS/MS}

Isolat senyawa steroid yang memiliki kemampuan antioksidan yang paling baik dianalisis menggunakan LC-MS/MS. Kolom yang digunakan dengan spesifikasi hypersil gold (50 mm x 2,1 mm x 1,9 $\mu \mathrm{m})$. UHPLC merk ACCELLA type 1250 buatan Thermo Scientific yang terdiri dari degasser vakum, pompa quartener, autosampler. Thermostatic yang dikendalikan oleh komputer melalui program $x$-calibur 2.1. Fase gerak yang digunakan adalah $0,1 \%$ asam format dalam air (fase $A$ ) dan $0,1 \%$ asam format dalam asetonitril (fase B). Pengaturan eluen secara gradien linier $100 \%(A): 0 \%$ (B) sampai $0 \%(A)$ : $100 \%$ (B) yang diatur selama 5 menit dengan laju alir $500 \mu \mathrm{L} /$ menit. Volume yang diinjeksikan sebanyak $2 \mu \mathrm{L}$. Kolom dikontrol pada suhu $30^{\circ} \mathrm{C}$, dan kompartemen autosampler ditetapkan untuk $10^{\circ} \mathrm{C}$.

MS yang digunakan adalah MS/MS triple Q (Quadrupole) spektrometer massa TSQ QUANTUM ACCESS MAX dari Thermo Finnigan dengan sumber ionisasi APCI (Atmospheric Pressure Chemical lonization) dikendalikan oleh software TSQ Tune yang dikendalikan dengan mode positif. Kondisi ion APCL 41 adalah sebagai berikut: arus yang digunakan 4 $\mu \mathrm{A}$, suhu penguapan $250^{\circ} \mathrm{C}$, suhu kapiler $300^{\circ} \mathrm{C}$, sheath gas pressure 45 arbitrary units, dan aux gas pressure 15 arbitary units.

\section{Hasil dan Pembahasan}

\subsection{Preparasi Sampel}

Preparasi sampel meliputi pencucian untuk menghilangkan pengotor yang terdapat pada sampel dan pengeringan untuk mengurangi kandungan air. Proses pengeringan dilakukan tanpa pemanasan sinar matahari langsung. Pengeringan tanpa menggunakan pemanasan matahari ini dilakukan agar senyawa aktif yang diinginkan tidak mengalami kerusakan akibat suhu yang tinggi. Penghalusan bertujuan untuk memperluas permukaan dari sampel sehingga mempermudah pada tahap ekstraksi. Menurut Voight [38], semakin kecil bentuk sampel maka luas permukaannya akan semakin besar sehingga kontak yang terjadi antara sampel dengan pelarut akan semakin besar. Sampel yang telah dihaluskan dan diayak dengan ukuran \pm 90 mesh. Sampel kering sebanyak 1,1 kg menghasilkan serbuk kering sebanyak $950 \mathrm{~g}$.

\subsection{Penentuan Kadar Air secara Termogravimetri}

Kandungan air dalam sampel memiliki pengaruh besar terhadap proses ekstraksi. Menurut Khoiriyah dkk. [39], kadar air yang rendah dapat mempermudah proses penarikan zat aktif dalam sampel karena pelarut mudah menembus dinding sel sampel tanpa adanya gangguan dari molekul air. Hasil penentuan kadar air pada sampel kering $H$. verticillata sebesar $6,5 \%$. Nilai tersebut sesuai dengan Setyaningsih dkk. [40] menyatakan bahwa kadar air maksimum yang diisyaratkan untuk berlangsungnya ekstraksi secara maksimal yaitu sebesar $11 \%$. Artinya kadar air sampel kering $H$. verticillata tidak melebihi ambang batas maksimum kadar air yang disyaratkan untuk proses ekstraksi. Hal ini bertujuan agar sampel yang telah berbentuk ekstrak tidak ditumbuhi jamur saat disimpan [41].

\subsection{Ekstraksi Sampel}

Senyawa metabolit sekunder yang berada di alam berikatan dengan glikosida sehingga bersifat polar. Oleh karena itu, pada penelitian ini proses ekstraksi maserasi dilakukan dengan pelarut metanol yang bersifat polar. Proses maserasi dihentikan ketika warna filtrat dari sampel sudah berubah dari hijau pekat menjadi hijau yang lebih bening yang dapat diasumsikan bahwa senyawa dalam sampel telah terekstrak. Filtrat dari hasil proses maserasi menggunakan metanol yang telah diperoleh dijadikan satu dan diuapkan menggunakan rotary evaporator untuk memperoleh ekstrak pekat metanol. Rendemen ekstrak pekat yang didapat dari pada penelitian ini yaitu 5,14\%.

\subsection{Hidrolisis dan Partisi}

Senyawa organik yang terdapat pada tumbuhan dalam bentuk ikatan glikosida yaitu gabugan dua bagian senyawa antara gugus gula dan gugus bukan gula. Proses hidrolisis akan memutuskan ikatan glikosida menjadi glikon dan aglikon dengan bantuan katalis asam. Hidrolisat yang diperoleh kemudian dipartisi (ekstraksi cair-cair) dengan menggunakan pelarut $n$-heksana. Pelarut ini bersifat nonpolar sehingga dapat melarutkan senyawa yang bersifat nonpolar seperti senyawa steroid. Proses partisi menghasilkan dua fasa cairan di mana fasa air dan fasa organik pada lapisan atas. Proses ekstraksi dilakukan sebanyak tiga kali pengulangan untuk diambil fase organik yang mengandung senyawa steroid hingga 
terjadi perubahan dari hijau kehitaman berubah warnanya menjadi bening. Dari 10 gram ekstrak kasar yang dihidrolisis didapatkan fraksi pekat n-heksana sebanyak $4,7 \mathrm{~g}$ dengan randemen $47,95 \%$.

\subsection{Uji Fitokimia}

Uji fitokimia bertujuan untuk mengetahui senyawa steroid yang terdapat dalam sampel. Terbentuknya warna hijau kebiruan menunjukkan fraksi n-heksana $H$. verticillata mengandung golongan senyawa steroid sebagaimana yang ditunjukkan pada Gambar 1(a).

\subsection{Pemisahan Senyawa Steroid dengan Kromatografi Lapis Tipis (KLT)}

\subsubsection{Pemisahan dengan KLT Analitik}

Hasil ilustrasi pola pemisahan variasi eluen pada KLT analitik saat diamati di bawah lampu UV $366 \mathrm{~nm}$ tergambar pada Gambar 1(b). Pola pemisahan pada eluen $5(3,75: 1,25)$ dan $4(4: 1)$ menghasilkan jumlah noda yang sama dan terbanyak daripada variasi eluen lainnya. Meskipun demikian, variasi eluen 4 memiliki pola pemisahan noda yang terduga steroid lebih bagus dibandingkan dengan variasi eluen 5 karena adanya jarak yang jelas antara senyawa terduga steroid dengan senyawa terduga triterpenoid.

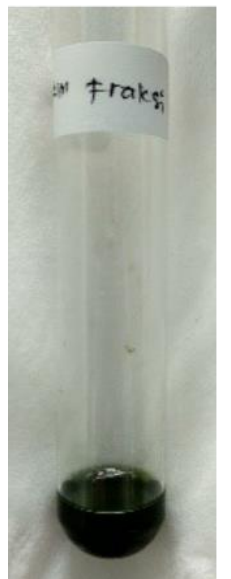

(a)

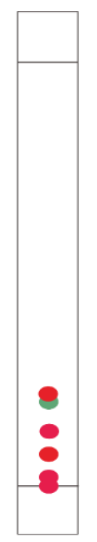

4,75: 0,25

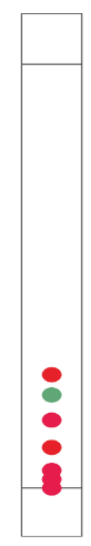

4,5: 0,5

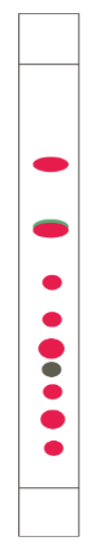

(b)

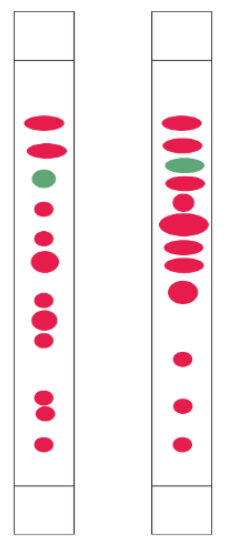

4: $1 \quad 3,75: 1,25$

Gambar 1. (a) Uji fitokimia fraksi n-heksana H. verticillata, dan (b) Penampakan noda KLT analitik pada $366 \mathrm{~nm}$.

Tabel 2. Jumlah Noda yang Terbentuk pada KLT Analitik

\begin{tabular}{|c|c|c|c|c|c|c|c|}
\hline Eluen & $\begin{array}{c}\text { Jumlah } \\
\text { Noda }\end{array}$ & $\mathrm{Rf}$ & Warna & $\begin{array}{l}\text { Dugaan } \\
\text { Senyawa }\end{array}$ & $\mathrm{Rf}$ & Warna & $\begin{array}{l}\text { Dugaan } \\
\text { Senyawa }\end{array}$ \\
\hline 1 & 4 & 0,0375 & Merah & Triterpenoid & 0,1625 & Hijau & Steroid \\
\hline$(4,75: 0,25)$ & & 0,1 & Merah & Triterpenoid & 0,1875 & Merah & Triterpenoid \\
\hline 2 & 4 & 0,05 & Merah & Triterpenoid & 0,2125 & Hijau & Steroid \\
\hline$(4,50: 0,50)$ & & 0,0875 & Merah & Triterpenoid & 0,25 & Merah & Triterpenoid \\
\hline 3 & 9 & 0,075 & Merah & Triterpenoid & 0,35 & Merah & Triterpenoid \\
\hline \multirow[t]{4}{*}{$(4,25: 0,75)$} & & 0,15 & Merah & Triterpenoid & 0,425 & Merah & Triterpenoid \\
\hline & & 0,2 & Merah & Triterpenoid & 0,6 & Hijau & Steroid \\
\hline & & 0,25 & Merah & Triterpenoid & 0,7625 & Merah & Triterpenoid \\
\hline & & 0,2875 & Merah & Triterpenoid & & & \\
\hline 4 & 12 & 0,1125 & Merah & Triterpenoid & 0,5625 & Merah & Triterpenoid \\
\hline \multirow[t]{5}{*}{$(4,00: 1,00)$} & & 0,2 & Merah & Triterpenoid & 0,625 & Merah & Triterpenoid \\
\hline & & 0,25 & Merah & Triterpenoid & 0,675 & Merah & Triterpenoid \\
\hline & & 0,3625 & Merah & Triterpenoid & 0,725 & Hijau & Steroid \\
\hline & & 0,4 & Merah & Triterpenoid & 0,7875 & Merah & Triterpenoid \\
\hline & & 0,475 & Merah & Triterpenoid & 0,8625 & Merah & Triterpenoid \\
\hline 5 & 12 & 0,1625 & Merah & Triterpenoid & 0,6375 & Merah & Triterpenoid \\
\hline \multirow[t]{5}{*}{$(3,75: 1,25)$} & & 0,25 & Merah & Triterpenoid & 0,7 & Merah & Triterpenoid \\
\hline & & 0,325 & Merah & Triterpenoid & 0,7375 & Merah & Triterpenoid \\
\hline & & 0,4875 & Merah & Triterpenoid & 0,775 & Hijau & Steroid \\
\hline & & 0,5625 & Merah & Triterpenoid & 0,8125 & Merah & Triterpenoid \\
\hline & & 0,5875 & Merah & Triterpenoid & 0,8625 & Merah & Triterpenoid \\
\hline
\end{tabular}


Adapun variasi eluen $1(4,75: 0,25)$ dan $2(4,50: 0,50)$ menghasilkan jumlah noda yang sedikit (Gambar 1 (b)). Pada variasi eluen 1 memiliki jumlah noda sebanyak 9 , namun noda yang diduga steroid mengalami overlap dengan noda yang diduga senyawa triterpenoid. Berdasarkan hasil tersebut, variasi eluen 4 dengan perbandingan $n$-heksana : etil asetat yaitu 4:1 digunakan untuk analisis lebih lanjut pada pemisahan KLT preparatif.

Berdasarkan Tabel 2, dari kelima variasi eluen yang digunakan, variasi eluen 4 dan 5 menghasilkan jumlah noda terbanyak dengan jumlah yang sama yaitu 12, sedangkan pada variasi eluen $3(4,25: 0,75)$ hanya menghasilkan 9 noda. Adapun pada variasi eluen 1 dan 2 masing-masing menghasilkan 4 noda.

\subsubsection{Pemisahan dengan KLT Preparatif}

Pemisahan senyawa steroid dengan KLT preparatif dilakukan untuk mendapatkan isolat steroid. Hasil pemisahan menggunakan KLT preparatif terbentuk 19 noda yang ditunjukkan pada Tabel 3. Berdasarkan Tabel 3, dapat diketahui terdapat 1 steroid dan 18 triterpenoid. Jumlah noda yang dihasilkan pada KLT preparatif tidak sama dengan KLT analitik. Hal ini dikarenakan jarak elusi yang berbeda sehingga pada KLT preparatif senyawa yang awalnya masih berhimpit akhirnya terpisah.

Tabel 3. Hasil Pemisahan Senyawa Steroid dengan KLT Preparatif

\begin{tabular}{cccccccc}
\hline No. & $\mathbf{R f}$ & Warna & Dugaan Senyawa & No. & $\mathbf{R f}$ & Warna & Dugaan Senyawa \\
\hline 1 & 0,067 & Merah & Triterpenoid & 11 & 0,4 & Merah & Triterpenoid \\
2 & 0,094 & Merah & Triterpenoid & 12 & 0,461 & Merah & Triterpenoid \\
3 & 0,12 & Merah & Triterpenoid & 13 & 0,51 & Merah & Triterpenoid \\
4 & 0,183 & Merah & Triterpenoid & 14 & 0,55 & Merah & Triterpenoid \\
5 & 0,21 & Merah & Triterpenoid & 15 & 0,66 & Merah & Triterpenoid \\
6 & 0,239 & Merah & Triterpenoid & 16 & 0,75 & Hijau & Steroid \\
7 & 0,283 & Merah & Triterpenoid & 17 & 0,8 & Merah & Triterpenoid \\
8 & 0,31 & Merah & Triterpenoid & 18 & 0,856 & Merah & Triterpenoid \\
9 & 0,36 & Merah & Triterpenoid & 19 & 0,917 & Merah & Triterpenoid \\
10 & 0,383 & Merah & Triterpenoid & & & & \\
\hline
\end{tabular}

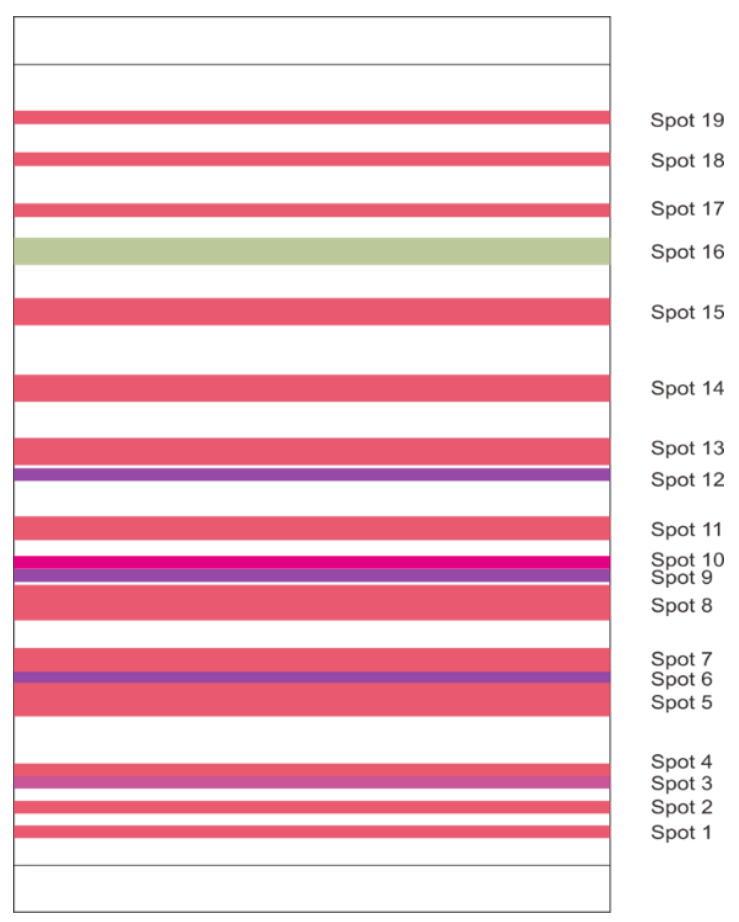

Gambar 2. Hasil pemisahan senyawa steroid dengan KLT preparatif.

Ilustrasi hasil pemisahan KLTP ditunjukkan pada Gambar 2. Pemisahan dengan KLT preparatif menghasilkan 1 noda positif steroid pada noda 16. Noda tersebut dikerok, dilarutkan dalam pelarutnya, dipisahkan menggunakan sentrifuge dan diuapkan pelarutnya. Isolat tersebut kemudian diuji antioksidannya menggunakan metode DPPH. 


\subsection{Uji Aktivitas Antioksidan dengan metode DPPH}

\subsubsection{Penentuan Panjang Gelombang Maksimum DPPH}

Penentuan panjang gelombang maksimum bertujuan untuk mengetahui panjang gelombang yang mempunyai serapan tertinggi. Pengukuran sampel dilakukan panjang gelombang maksimum untuk mengoptimalkan kepekaan DPPH dan meminimalkan kesalahan [42]. Panjang gelombang maksimum DPPH yang diperoleh sebesar $515 \mathrm{~nm}$ sebagaimana yang ditunjukkan pada Gambar 3. Panjang gelombang ini akan digunakan untuk menentukan aktivitas antioksidan pada isolat senyawa steroid hasil KLT fraksi n-heksana dari $H$. verticillata.

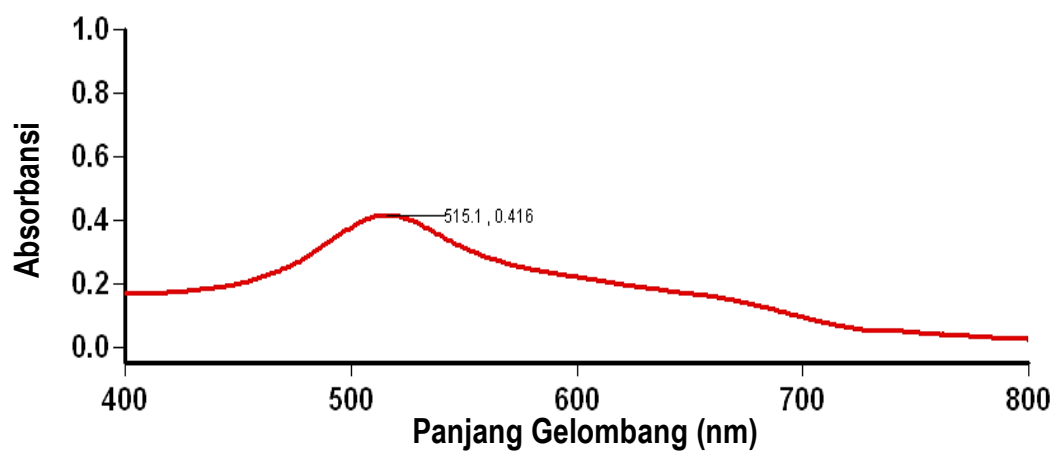

Gambar 3. Spektra panjang gelombang maksimum larutan DPPH.

\subsubsection{Pengukuran Aktivitas Antioksidan pada Sampel}

Persen aktivitas antioksidan pada isolat senyawa steroid hasil KLT preparatif dengan variasi konsentrasi 1, 2, 3, 4 dan 5 ppm ditunjukkan pada Tabel 4. Pembuatan larutan DPPH dibuat dalam keadaan baru untuk menghindari terjadinya perubahan nilai yang signifikan. Berdasarkan data pada Tabel 4, dapat diketahui nilai $\mathrm{EC}_{50}$ sampel yaitu sebesar 5,109 ppm. Suatu senyawa dikatakan sebagai antioksidan sangat kuat apabila memiliki nilai EC ${ }_{50}$ kurang dari 50 ppm [43].

Tabel 4. Hasil Pengukuran Persen Aktivitas Antioksidan pada Sampel

\begin{tabular}{cccc}
\hline Konsentrasi & Absorbansi Kontrol & Absorbansi Sampel & Aktivitas Antioksidan (\%) \\
\hline $1 \mathrm{ppm}$ & 0,1167 & 0,1125 & 3,59 \\
$2 \mathrm{ppm}$ & 0,4052 & 0,3849 & 5,009 \\
$3 \mathrm{ppm}$ & 0,1173 & 0,0973 & 17,05 \\
$4 \mathrm{ppm}$ & 0,7741 & 0,5601 & 27,6 \\
$5 \mathrm{ppm}$ & 0,7774 & 0,3875 & 50,154 \\
\hline
\end{tabular}

\subsection{Identifikasi Senyawa Steroid}

\subsubsection{Identifikasi dengan Spektrofotometer UV-Vis}

Berdasarkan Gambar 4, isolat steroid menghasilkan serapan maksimum pada panjang gelombang 203,9 dan 276 nm. Panjang gelombang $203 \mathrm{~nm}$ terdapat ikatan $C=C$ tidak terkonjugasi dengan transisi $\pi-\pi^{*}$. Sesuai dengan penelitian Aprelia dan Suyatno [44] yang melakukan identifikasi senyawa metabolit sekunder pada tumbuhan paku terdapat adanya serapan maksimum pada $203 \mathrm{~nm}$ yang menunjukkan adanya senyawa $\beta$-sitosterol, sedangkan panjang gelombang 276 $\mathrm{nm}$ menunjukkan bahwa hasil isolasi ini memiliki ikatan rangkap terkonjugasi.

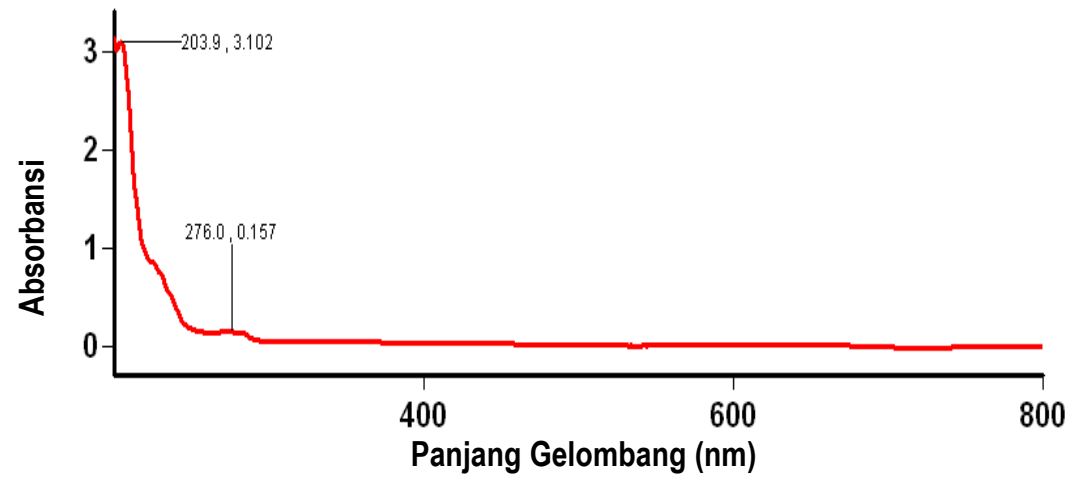

Gambar 4. Spektra UV-Vis pada isolat steroid hasil KLT preparatif. 


\subsubsection{Identifikasi dengan FTIR}

FTIR merupakan suatu metode yang digunakan untuk mengidentifikasi gugus fungsi suatu senyawa dimana terjadi interaksi antara energi dengan molekul yang menyebabkan terjadinya transisi akibat adanya vibrasi molekul sehingga setiap gugus fungsi mempunyai tipe ikatan yang berbeda dan serapan IR yang khas. Spektra FTIR dari isolate steroid $H$. verticillata dapat dilihat pada Gambar 5.

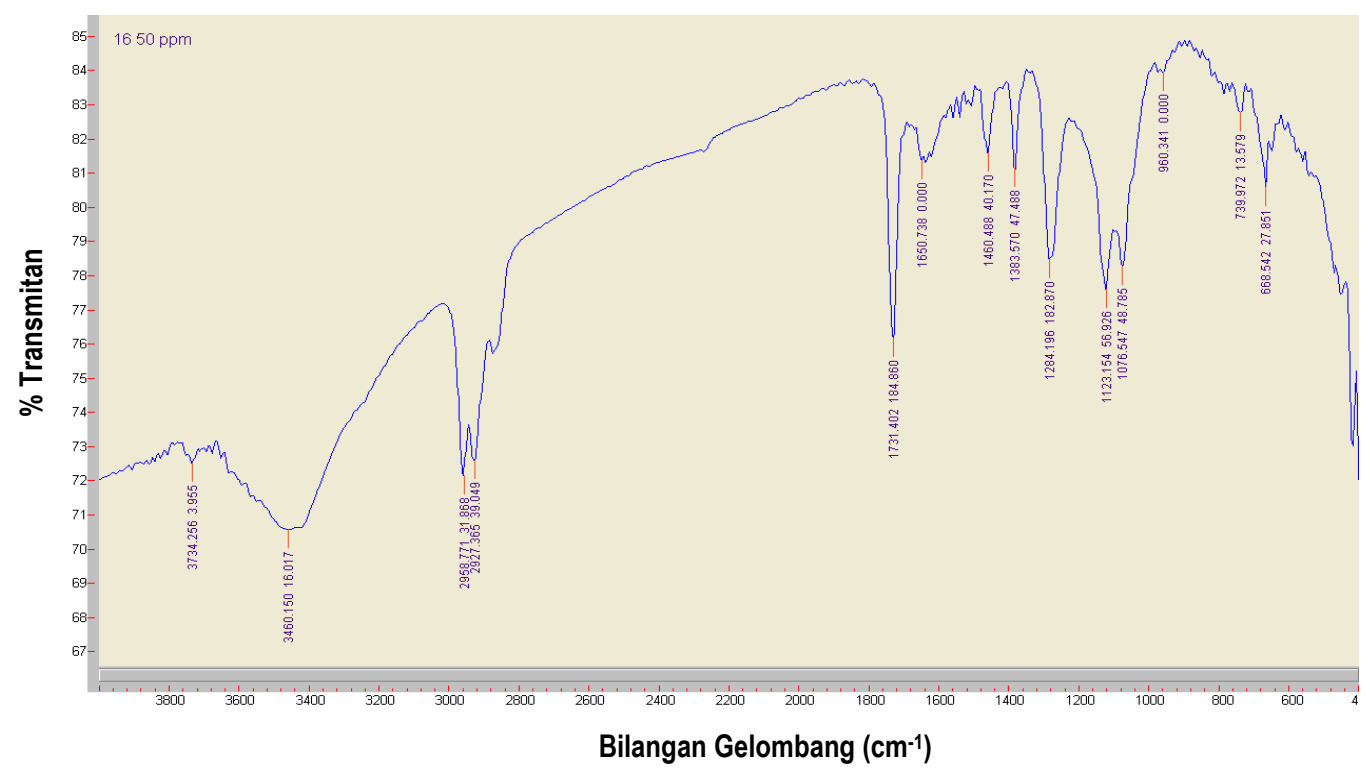

Gambar 5. Spektra FTIR isolat steroid hasil KLT preparatif.

Hasil analisis pola serapan FTIR yang dihasilkan dari isolat steroid $H$. verticillata menunjukkan adanya pita serapan pada daerah $3460,150 \mathrm{~cm}^{-1}$ yang melebar menunjukkan adanya gugus $\mathrm{O}-\mathrm{H}$ pada isolat. Pita serapan $2958,771 \mathrm{~cm}^{-1}$ menunjukkan $\mathrm{CH}_{3}$ stretching, $-\mathrm{CH}_{2}$-asiklik $\left(2927\right.$ dan $\left.2840 \mathrm{~cm}^{-1}\right)$ dan ikatan $\mathrm{C}=\mathrm{C}\left(1650 \mathrm{~cm}^{-1}\right)$. Gugus fungsi penting lainnya yaitu gugus karbonil $\mathrm{C}=\mathrm{O}$ untuk ester $\left(1731 \mathrm{~cm}^{-1}\right)$ yang didukung dengan serapan $\mathrm{C}-\mathrm{O}$ ester $\left(1286 \mathrm{~cm}^{-1}\right)$ dan serapan $\mathrm{C}$ O-C (1076 $\left.\mathrm{cm}^{-1}\right)$. Serapan C-O untuk alkohol sekunder muncul 1123,154 $\mathrm{cm}^{-1}$. Gugus geminal dimetil pada bilangan gelombang $1460 \mathrm{~cm}^{-1}$ dan 1383,5 $\mathrm{cm}^{-1}$. Serapan gugus geminal dimetil ini adalah serapan khas dari senyawa steroid dan triterpenoid [45].

\subsubsection{Identifikasi dengan LC-MS/MS}

Identifikasi dilakukan pada isolat steroid yang didapat dari pemisahan menggunakan KLT. LC-MS/MS merupakan salah satu instrumen yang dapat memisahkan senyawa berdasarkan berat dan struktur molekul, serta distribusi kepolarannya terhadap fasa diam dan fasa gerak yang digunakan. Dugaan jenis steroid hasil identifikasi LC-MS/MS berdasarkan waktu retensi dan nilai $\mathrm{m} / \mathrm{z}$ yang terdapat pada Tabel $\mathbf{5}$. Berdasarkan Tabel 5, diketahui bahwa isolat hasil $\mathrm{KLT}$ preparatif fraksi $\mathrm{n}$-heksana hasil hidrolisis ekstrak metanol $\mathrm{H}$. verticillata menghasilkan spektra massa dengan $\mathrm{m} / \mathrm{z}$ ion prekursor sebesar 397 dan $\mathrm{m} / \mathrm{z}$ ion produk sebesar 161. Nilai ini sesuai dengan ion prekursor dan ion produk senyawa steroid $\beta$-sitosterol. Struktur ion prekursor, ion produk dan $\beta$-sitosterol ditunjukkan pada Gambar 6.

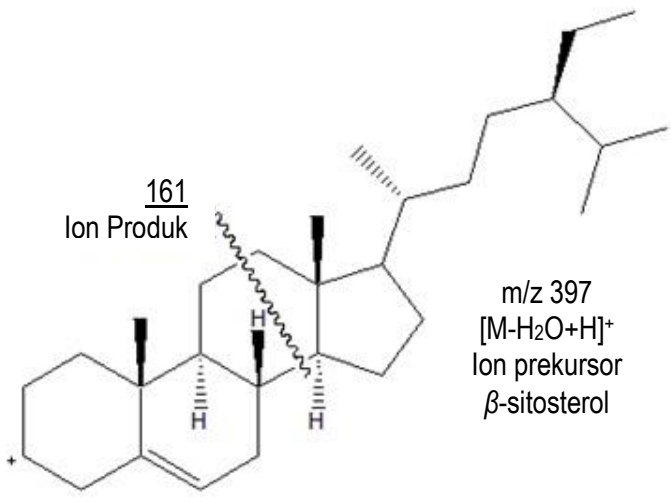

(a)

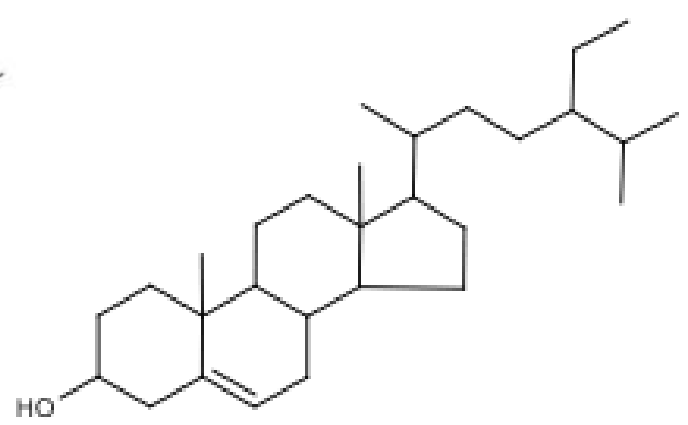

(b)

Gambar 6. (a) Struktur ion prekursor dan ion produk [18], dan (b) struktur $\beta$-sitosterol. 
Tabel 5. Hasil Identifikasi LC-MS/MS Isolat Steroid H. verticillata

\begin{tabular}{ccccccc}
\hline \multirow{2}{*}{ Jenis Steroid } & $\begin{array}{c}\text { Waktu Retensi } \\
\text { (Menit) }\end{array}$ & $\mathbf{M}$ & $\mathbf{M}-\mathrm{H}_{2} \mathbf{O}$ & lon Prekursor & lon Produk & Kelimpahan \\
\cline { 3 - 6 } & 2,26 & 414 & 396 & 397 & $160,5-161,5$ & 1326 \\
\hline B-sitosterol & 2,26 & & & & &
\end{tabular}

\section{Kesimpulan}

Pemisahan steroid fraksi n-heksana pada $H$. verticillata menggunakan KLT dengan variasi eluen n-heksana dan etil asetat. Pemisahan terbaik untuk memisahkan steroid dengan KLT analitik menggunakan eluen 4 (4:1) dengan 12 noda. Pemisahan steroid menggunakan KLT preparatif menghasilkan 19 noda dimana 1 noda yang diduga steroid. Aktivitas antioksidan isolat steroid hasil KLT preparatif menghasilkan nilai EC $_{50}$ sebesar 5,109 ppm yang menunjukkan aktivitas antioksidan yang sangat kuat. Hasil identifikasi dengan spektrofotometer UV-Vis, FTIR dan LC-MS/MS menunjukkan bahwa isolat hasil KLT preparatif fraksi $n$-heksana hasil hidrolisis ekstrak metanol $H$. verticillata mengandung senyawa steroid $\beta$-sitosterol.

\section{Daftar Pustaka}

[1] F. Goltenboth, K. H. Timotius, P. P. Milan, \& J. Margraf, Ekologi Asia Tenggara Kepulauan Indonesia. Jakarta: Salemba Teknika, 2012.

[2] A. Artiyani, "Penurunan Kadar N-Total dan P-Total pada Limbah Cair Tahu dengan Metode Fitoremediasi Aliran Batch dan Kontinyu Menggunakan Tanaman Hydrilla verticillata," Spectra, vol. 9, no. 18, pp. 9-14, 2011.

[3] H. Araki, M. Inoue, \& T. Katoh, "Total synthesis and Absolute Configuration of Otteliones A and B, Novel and Potent Antitumor Agents from a Freshwater Plant," Organic Letters, vol. 5, no. 21, pp. 3903-3906, 2003.

[4] B. Das, D. Pal, \& A. Haldar, "Pharmacognostical and Physiochemical Study of the Aquatic Weed Hydrilla verticillata (L.f.) Royle Known as Nutrient Power House," International Journal of Research in Pharmacy and Science, vol. 5, no. 1, pp. 1-6, 2015.

[5] P. Prabha \& J. Rajkumar, "Phytochemical Screening and Bioactive Potential of Hydrilla verticillata," Journal of Chemical and Pharmaceutical Research, vol. 7, no. 3, pp. 1809-1815, 2015.

[6] S. W. Annie, R. Raveen, M. G. Paulraj, T. Samuel, \& S. Arivoli, "Screening of Hydrilla verticillata (L. F.) Royle (Hydrocharitaceae) Crude Leaf Extracts for Larvicidal Efficacy against the Filarial Vector Culex quinquefasciatus Say (Diptera: Culicidae)," International Journal of Entomology Research, vol. 1, no. 3, pp. 43-48, 2016.

[7] D. K. Pal \& S. B. Nimse, "Little Known Uses of Common Aquatic Plant, Hydrilla verticillata (Linn. f.) Royle," Natural Product Radiance, vol. 5, no. 2, pp. 108-111, 2006.

[8] A. G. Fasya, S. Amalia, D. S. Megawati, F. Salima, V. A. Kusuma, \& B. Purwantoro, "Isolation, Identification, and Bioactivity of Steroids Isolates from Hydrilla verticillata Petroleum Ether Fraction," in IOP Conference Series: Earth and Environmental Science on the 10 th International Conference on Green Technology, vol. 456, no. 012009, 2020.

[9] Z. J. Yi, J. Yao, M. J. Zhu, H. L. Chen, F. Wang, \& X. Liu, "Uranium Biosorption from Aqueous Solution by the Submerged Aquatic Plant Hydrilla verticillata," Water Science and Technology, vol. 75, no. 5-6, pp. 1332-1341, 2017.

[10] V. M. Kensa \& R. Neelamegam, "Preliminary Phytochemical Analysis of Hydrilla verticillata (L.F.) Royle. Collected from Polluted and Unpolluted Water Sources," International Journal of Informative \& Futuristic Research, vol. 3, no. 3, pp. 1125-1128, 2015.

[11] K. Roma, S. Kiran, \& D. Sahoo, "Extraction and Screening of Bioactive Compounds of Some Common Hydrophyticand Wetland Plants from East Singbhum, Jharkhand, India," IOSR Journal of Pharmacy, vol. 7 no. 11, pp. 23-29, 2017.

[12] S. Amalia, A. G. Fasya, F. Hasanah, \& D. Yuliani, "Pemisahan Senyawa Aktif Fraksi Petroleum Eter dan Etil Asetat Hasil Hidrolisis Ekstrak Etanol Hydrilla verticillata Pasuruan dari Ranu Grati, ALCHEMY: Journal of Chemistry, vol. 6 , no. 2, pp. 50-56, 2018.

[13] U. Mardiyah, "Uji Aktivitas Antioksidan terhadap 1,1-Difenil-2-Pikrilhidrazil (DPPH) dan Identifikasi Golongan Senyawa Aktif Alga Merah Eucheuma spinosum dari Perairan Banyuwangi," Skripsi, Universitas Islam Negeri Maulana Malik Ibrahim, Malang, 2012.

[14] S. Lenny, "Senyawa Flavonoida, Fenil Propanoida dan Alkaloida," USU Repository, 2006.

[15] S. Atun, "Metode Isolasi dan Identifikasi Struktur Senyawa Organik Bahan Alam," Jurnal Konservasi Cagar Budaya Borobudur, vol. 8, no. 2, pp. 53-61, 2014.

[16] M. N. Hafiz, "Uji Toksisitas Ekstrak Metanol, Kloroform dan n-Heksana Hydrilla verticillata (L.f) Royle dari Danau Ranu Kab. Pasuruan terhadap Larva Udang Artemia salina Leach," Skripsi, Universitas Islam Negeri Maulana Malik Ibrahim, Malang, 2017. 
[17] A. G. Fasya, A. Baderos, A. D. R. Madjid, S. Amalia, \& D. S. Megawati, "Isolation, Identification, and bioactivity of Steroids Compounds from Red Algae Eucheuma cottonii Petroleum Ether Fraction," in AIP Conference Proceedings, vol. 2120, no.1, 2019.

[18] I. Khalaf, A. Corciovia, L. Vlase, B. Ivanescu, \& D. Lazar, "LC/MS Analysis of Sterolic Compounds from Glycyrrhiza glabra," Studia UBB Chemia, vol. 3, no. 1, pp. 97-102, 2011.

[19] D. S. P. Handoko, "Kinetika Hidrolisis Maltosa pada Variasi Suhu dan Jenis Asam sebagai Katalis," SIGMA: Jurnal Sains dan Teknologi, vol. 9, no. 1, 2006.

[20] A. G. Fasya, A. R. Dinasti, M. Shofiyah, L. M. Rahmawati, N. Millati, D. A. Safitri, S. Handoko, A. Hanapi, \& R. Ningsih, "Ekstraksi, Hidrolisis dan Partisi Metabolit Sekunder dari mikroalga Chorella sp.," ALCHEMY: Journal of Chemistry, vol. 5, no. 1, pp. 5-9, 2016.

[21] J. Tonius, M. A. Wibowo, \& N. Idiawati, "Isolasi dan Karakterisasi Senyawa Steroid Fraksi n-Heksana Daun BuasBuas (Premna serratifolia L.)," Jurnal Kimia Khatulistiwa, vol. 5, no. 1, pp. 1-7, 2016.

[22] A. Mohammad, S. A. Bhawani, \& S. Sharma, "Analysis of Herbal Products by Thin-Layer Chromatography: A Review," International Journal of Pharma and Bio Sciences, vol. 1, no. 2, pp. PS16, 2010.

[23] D. S. Megawati, A. G. Fasya, R. A. Pratiwi, \& N. Maghfiroh, "Pharmacology Potency of Thin Layer Chromatography Steroid Isolates of Chlorella sp. Chloroform Fraction," IOP Conference Series Earth and Environmental Science, vol. 456, no. 012012, 2020.

[24] I. Mardaneni, "Pemisahan Senyawa Steroid Fraksi Etil Asetat Alga Merah Eucheuma cottonii Perairan Wongsorejo Banyuwangi Menggunakan Metode KLT dan LC-MS," Skripsi, Universitas Islam Negeri Maulana Malik Ibrahim, Malang, 2017.

[25] A. Baderos, "Pemisahan Senyawa Steroid Fraksi Petroleum Eter Alga Merah (Eucheuma cottonii) dengan Metode Kromatografi Lapis Tipis dan Identifikasi Menggunakan LC-MS," Skripsi, Universitas Islam Negeri Maulana Malik Ibrahim, Malang, 2017.

[26] S. N. Azah, "Uji Toksisitas dan Identifikasi Isolat Steroid Hasil KLTP Ekstrak n-Heksana dan Petroleum Eter Hydrilla verticillata Menggunakan UV-Vis dan LC-MS/MS," Skripsi, Universitas Islam Negeri Maulana Malik Ibrahim, Malang, 2019.

[27] S. Ikfi, "Uji Antioksidan Ekstrak Metanol, Kloroform dan n-Heksana Hydrilla verticillata (L.f) Royle dari Danau Ranu Kab. Pasuruan Menggunakan Metode DPPH (1,1-diphenyl-2-picrylhydrazyl)," Skripsi, Universitas Islam Negeri Maulana Malik Ibrahim, Malang, 2017.

[28] R. Laili, "Uji Aktioksidan dan Identifikasi Menggunakan Spektrofotometer UV-Vis Senyawa Steroid Fraksi Petroleum Eter Hasil Hidrolisis Ekstrak Metanol Alga Merah," Skripsi, Universitas Islam Negeri Maulana Malik Ibrahim, Malang, 2016.

[29] A. G. Fasya, N. Millati, L. M. Rahmawati, R. lyani, A. Hanapi, R. Ningsih, D. Yuliani, \& D. S. Megawati, "Isolation and Bioactivity of Steroids Isolates from Petroleum Ether Fraction of Chlorella sp.," in AIP Conference Proceedings, vol. 2243, no. 1, 2020.

[30] N. Imamah, "Pemisahan Senyawa Steroid Fraksi Etil Asetat Hasil Hidrolisis Ekstrak Metanol Mikroalga Chlorella sp. Menggunakan Kromatografi Lapis Tipis (KLT) dan Identifikasinya Menggunakan Spektrofotometer FTIR," Skripsi, Universitas Islam Negeri Maulana Malik Ibrahim, Malang, 2015.

[31] I. Sriwahyuni, "Uji Fitokimia Ekstrak Tanaman Anting-Anting (Acalypha indica Linn) dengan Variasi Pelarut dan Uji Toksisitas Menggunakan Brine Shrimp (Artemia salina Leach)," Skripsi, Universitas Islam Negeri Maulana Malik Ibrahim, Malang, 2010.

[32] Muharram, "Isolasi dan Uji Bioaktivitas Senyawa Metabolit Sekunder Ekstrak N-Heksan Daun Pare (Momordica charantia L.)," Bionature, vol. 11, no. 2, pp. 70-78, 2010.

[33] U. Zahra, Muharram, \& A. Ilyas, "Isolasi dan Identifikasi Senyawa Metabolit Sekunder Ekstrak n-Heksan dari Umbi Lobak (Raphanus sativus Lamk)," Al-Kimia, vol. 1, no. 1, pp. 1-9, 2013.

[34] L. N. Azizah, "Uji Toksisitas Isolat Steroid Hasil KLTP Fraksi Petroleum Eter Hasil Hidrolisis Ekstrak Metanol Alga Merah," Skripsi, Universitas Islam Negeri Maulana Malik Ibrahim, Malang, 2016.

[35] E. K. Hayati, A. Jannah, \& R. Ningsih, "Identifikasi Senyawa dan Aktivitas Antimalaria In Vivo Ekstrak Etil Asetat Tanaman Anting-Anting (Acalypha indica L.)," Molekul, vol. 7. no. 1. pp. 20-32, 2012.

[36] I. Dukomalamo, M. S. Sangi, \& J. A. Rorong, "Analisis Senyawa Toksik Tepung Pelepah Batang Aren (Arenga pinnata) dengan Spektroskopi UV-Vis dan Inframerah," Jurnal MIPA, vol. 5, no. 1. pp. 54-59, 2016.

[37] E. Hanani, A. Mun'im, \& R. Sekarini, "Identifikasi Senyawa Antioksidan dalam Spons Callyspongia sp. dari Kepulauan Seribu," Majalah IImu Kefarmasian, vol. 2, no. 3, pp. 127-133, 2005.

[38] R. Voigt, Buku Pelajaran Teknologi Farmasi Edisi 5. Yogyakarta: Gadjah Mada University Press, 1995.

[39] S. Khoiriyah, A. Hanapi, \& A. G. Fasya, "Uji Fitokimia dan Aktivitas Antibakteri Fraksi Etil Asetat, Kloroform dan Petroleum Eter Ekstrak Metanol Alga Coklat Sargassum vulgare dari Pantai Kapong Pamekasan Madura," ALCHEMY, vol. 3, no. 2, pp. 133-144, 2014. 
[40] D. Setyaningsih, O. Y. Nurmillah, \& S. Windawati, "Kajian Aktivitas Antioksidan dan Antimikroba Ekstrak Biji, Kulit Buah, Batang dan Daun Tanaman Jarak Pagar (Jatropha curcas L.)," Jurnal Teknologi Pangan, vol. 4, no. 2, pp. 1-7, 2010.

[41] R. D. Ratnani, I. Hartati, Y. Anas, D. E. Puspaningrum, \& D. D. D. Khilyati, "Standarisasi Spesifik dan Non Spesifik Ekstraksi Hidrotropi Andrographolid dari Sambiloto," dalam Prosiding Seminar Nasional Peluang Herbal sebagai Alternatif Medicine, 2015, pp. 147-155.

[42] A. Rohman, Kimia Farmasi Analisis. Yogyakarta: Pustaka Pelajar, 2007.

[43] B. Hidajat, "Penggunaan Antioksidan pada Anak," Continuing Education XXXV. Hot Topics in Pediatric, pp. 3-4, 2005.

[44] F. Aprelia \& Suyatno, "Senyawa Metabolit Sekunder dari Ekstrak Etil Asetat Tumbuhan Paku Christella arida dan Uji Pendahuluan Sebagai Antikanker," UNESA Journal of Chemistry, vol. 2, no. 3, pp. 93-99, 2013.

[45] M. D. Astuti, A. Maulana, \& E. M. Kuntowati, "Isolasi Steroid dari Fraksi n-Heksana Batang Bajakah Tampala (Spatholobus littoralis Hassk.)," dalam Prosiding Seminar Nasional Kimia Jurusan Kimia FMIPA Universitas Negeri Surabaya, 2014, pp. B-9 - B-12 . 